\title{
IMPLEMENTASI PRINSIP SYARIAH TERHADAP PENYITAAN JAMINAN FIDUSIA
}

\author{
Iffaty Nasyi'ah dan Asna Jazillatul Chusna \\ Fakultas Syariah UIN Maulana Malik Ibrahim Malang \\ Email: iffaty.nasyiah@gmail.com
}

\begin{abstract}
Abstrak
This research aims at comparing the foreclosure process of fiduciary collateral between Fiduciary regulation (Law N. 42 of 1999) and the principles of Shariah and the compatibility of the foreclosure process with the the principles of Shariah as well as consumer protection principles. This is a literary research (Bibliography Research), which uses the written data sources such as al-Quran and al-Hadith, relevant legislation. The research reveals that the foreclosure process of fiduciary collateral is based on Fiduciary Law, some procedures are in accordance with Islamic principles except in the case of delay of payment provided by the creditor to the debitor and the consent of the competent institutions in foreclosure cases to be performed. However, Adage "the privity of contract" under consumer protection laws are not accommodated in the foreclosure process by Fiduciary Law. Creditors still use the standard contract that led to the dominance of the creditor against the debtor.

Penelitian ini bertujuan untuk membandingkan proses penyitaan jaminan fidusia antara UU Jaminan Fidusia (UU Nomor 42 tahun 1999) dan prinsip-prinsip Syariah dan kesesuain proses penyitaan jaminan sesuai dengan prinsip-prinsip syariah dan prinsip-prinsip perlindungan konsumen. Jenis penelitian ini adalah penelitian kepustakaan (Bibliography Research), yang menggunakan sumber data tertulis seperti; al-Qur'an dan al-Hadis dan perundang-undangan terkait. Hasil dari penelitian ini adalah bahwa pada proses penyitaan jaminan fidusia berdasarkan UU Jaminan Fidusia, beberapa prosedur telah sesuai dengan prinsip-prinsip syariah kecuali dalam hal adanya penundaan pembayaran yang diberikan oleh pihak kreditur kepada debitur serta adanya ijin dari lembaga yang berwenang untuk dilakukan penyitaan. Adagium the privity of contract" dalam hukum perlindungan konsumen masih belum diakomodir secara menyeluruh dalam proses penyitaan menurut UU Jaminan Fidusia. Kreditur masih menggunakan perjanjian baku yang mengarah pada adanya dominasi pihak kreditur terhadap debitur. Penggunaan prinsip-prinsip syariah dalam proses penyitaan telah mengakomodir prinsip-prinsip penyitaan dalam UU Jaminan Fidusia sekaligus menurut UU Perlindungan Konsumen.
\end{abstract}

Kata kunci: fidusia, penyitaan, perlindungan konsumen

Banyaknya kasus yang terjadi mengenai penyitaan barang dengan jaminan fidusia masih menjadi perbincangan yang panjang. Salah satu contoh kasus yang terjadi adalah sebagaimana diberitakan dalam DETIK.Com pada bulan April 2012. Sekelompok masa mendatangi ADIRA Finance karena beberapa dari mereka mendapatkan perlakuan yang sewenang-wenang dari lembaga pembiayaan tersebut. Salah satu sebab munculnya fenomena seperti diatas adalah pencantuman klausula baku pada perjanjian kredit yang memuat adanya "penyerahan hak milik secara Fidusia". Di dalam klausula baku tersebut juga dinyatakan 
bahwa konsumen memberikan kuasa kepada lembaga pembiayaan untuk melakukan segala tindakan terkait obyek jaminan fidusia.

Pencantuman klausula baku tersebut dilarang oleh Undang-Undang perlindungan konsumen No. 8 tahun 1999 sebagaimana ditentukan dalam pasal 18 ayat (1) poin d yang menyatakan"pemberian kuasa dari konsumen kepada pelaku usaha baik secara langsung maupun tidak langsung untuk melakukan segala tindakan sepihak yang berkaitan dengan barang yang dibeli oleh konsumen secara angsuran."

Penyitaan yang dilakukan oleh debt collector atas persetujuan kreditur dikarenakan debitur telah menandatangani perjanjian kredit yang mencantumkan adanya klausula baku sebagaimana diatas. Klausula baku yang dicantumkan oleh pihak kreditur tersebut disandarkan pada pasal 15 ayat 3 undang-undang Jaminan fidusia selanjutnya disingkat UUJF No. 42 tahun 1999 yang berbunyi: "Apabila debitur cidera janji, Penerima Fidusia mempunyai hak untuk menjual Benda yang menjadi objek Jaminan Fidusia atas kekuasaannya sendiri".

Sebenarnya penyitaan atau eksekusi jaminan fidusia telah diatur dalam UUJF pasal 29 sampai dengan pasal 34, akan tetapi ketentuan ini masih banyak terdapat penyimpangan di lapangan. Salah satunya adalah bahwa jaminan fidusia tidak didaftarkan ke Kantor Pendaftaran Fidusia dengan pertimbangan biaya yang akan ditanggung oleh pihak kreditur. Pasal 15 UUJF memberikan pengertian secara a contrario bahwa barang jaminan fidusia yang tidak didaftarkan tidak boleh disita secara sepihak atau secara langsung (parate executie) melainkan harus dengan persetujuan debitur dengan melalui surat peringatan terlebih dahulu.

Jika dalam hukum positif permasalahan di atas dimasukkan dalam pembahasan mengenai fidusia, maka dalam hukum Islam jaminan fidusia dikategorikan dalam Rahn Tasjily. Esensi Rahn Tasjily sendiri identik dengan jaminan fidusia, karena definisi dari Rahn Tasjily adalah jaminan dalam bentuk barang atas hutang tetapi barang jaminan tersebut (marhun) tetap berada dalam penguasaan (pemanfaatan) rahin dan bukti kepemilikannya diserahkan kepada murtahin. ${ }^{1}$

Fatwa DSN-MUI No. 68/DSN-MUI/III 2008 telah mengatur mengenai Rahn Tasjily berikut ketentuan penyitaannya yang berbunyi "penyimpangan barang jaminan dalam bentuk bukti yang sah kepemilikan atau sertifikat tersebut tidak memindahkan kepemilikan barang ke murtahin. Apabila terjadi wanprestasi atau tidak dapat melunasi hutangnya, marhun dapat dijual paksa atau dieksekusi langsung baik melalui lelang atau dijual ke pihak lain sesuai prinsip syariah."

Pelaku usaha dan konsumen yang beragama Islam, menjadikan hukum ekonomi Islam sebagai landasan dalam menyelesaikan sebuah perkara yang berdasarkan asas personalitas ke-Islaman, seharusnya diselesaikan di Pengadilan Agama termasuk perkara mengenai fidusia atau Rahn Tasjily ini, meskipun peraturan mengenai Islam masih belum dalam taraf Undang-Undang, seperti Kompilasi Hukum Ekonomi Islam dan fatwa-fatwa dari DSN-MUI.

\section{Metode Penelitian}

Jenis penelitian ini adalah penelitian kepustakaan (Bibliography Research), yang menggunakan sumber data tertulis seperti, al-Qur' an dan al-Hadis, peraturan perundang-undangan terkait, dan buku-buku yang mendukung penelitian. Dalam penelitian ini akan dicari data-data tertulis mengenai jaminan fidusia, penyitaan jaminan fidusia, UU jaminan fidusia, peraturan terkait mengenai jaminan fidusia, fatwa DSN-MUI yang relevan dengan jaminan fidusia, serta hukum Islam yang membahas tentang jaminan fidusia.

Kemudian pendekatan yang dilakukan dalam penelitian ini adalah kualitatif-normatif dengan menggunakan kajian-kajian pustaka sebagai sumber data yang akan dianalisis. Hasil akhir dari penelitian yang tidak hanya sekedar menghasilkan data atau informasi yang sulit dicari melalui metode kualitatif, melainkan juga menghasilkan informasi-informasi yang representatif dengan penelitian.

\footnotetext{
${ }^{1}$ Fatwa DSN-MUI 6 Maret 2008
} 


\section{Hasil dan Pembahasan}

Fidusia menurut asal katanya berasal dari bahasa Romawi fides yang berarti kepercayaan. Fidusia merupakan istilah yang sudah lama dikenal dalam bahasa Indonesia. Begitu pula istilah ini digunakan dalam Undang-undang Nomor 42 Tahun 1999 tentang Jaminan Fidusia. Dalam terminologi Belanda istilah ini sering disebut secara lengkap yaitu Fiduciare Eigendom Overdracht (F.E.O.) yaitu penyerahan hak milik secara kepercayaan. Sedangkan dalam istilah bahasa Inggris disebut Fiduciary Transfer of Ownership. Pengertian fidusia adalah pengalihan hak kepemilikan suatu benda atas dasar kepercayaan dengan ketentuan bahwa benda yang hak kepemilikannya dialihkan tetap dalam penguasaan pemilik benda.

Jaminan fidusia adalah jaminan kebendaan atas benda bergerak baik yang berwujud maupun tidak berwujud sehubungan dengan hutang-piutang antara debitur dan kreditur. Jaminan fidusia diberikan oleh debitur kepada kreditur untuk menjamin pelunasan hutangnya. Jaminan fidusia ini memberikan kedudukan yang diutamakan privilege kepada penerima fidusia terhadap kreditur lainnya.

Proses terjadinya jaminan fidusia dilaksanakan melalui dua tahap, yaitu tahap pembebanan dan tahap pendaftaran jaminan fidusia. Pembebanan jaminan fidusia dilakukan dengan menggunakan instrumen yang disebut dengan "Akta Jaminan Fidusia". Akta Jaminan Fidusia ini harus memenuhi syaratsyarat sebagai berikut: pertama harus berupa akta notaris, kedua harus dibuat dalam bahasa Indonesia, ketiga harus berisikan sekurangkurangnya hal-hal sebagai berikut: a. identitas para pihak, b. harus dicantumkan hari, tanggal, dan mengenai waktu (jam) pembuatan akta fidusia, c. data perjanjian pokok yang dijamin dengan fidusia, d. uraian mengenai benda yang menjadi objek jaminan fidusia yakni tentang identifikasi benda tersebut dan surat bukti kepemilikannya. Jika bendanya selalu berubah-ubah, seperti benda dalam persediaan (inventory) haruslah disebutkan tentang jenis, merk dan kualitas dari benda tersebut, e. berapa nilai dari penjaminan, f. berapa nilai benda yang menjadi objek jaminan fidusia.

Selain beberapa syarat yang wajib ada dalam suatu akta notaris tentang jaminan fidusia, perlu diberikan penegasan tentang hutang yang pelunasannya dijamin dengan jaminan fidusia. Menurut Pasal 7 UUJF, hutang yang pelunasannya dijamin dengan jaminan fidusia dapat berupa: 1 . hutang yang telah ada, 2. hutang yang akan timbul di kemudian hari yang telah diperjanjikan dalam jumlah tertentu, 3. hutang yang pada saat eksekusi dapat ditentukan jumlahnya berdasarkan perjanjian pokok yang menimbulkan kewajiban memenuhi suatu prestasi.

Untuk mendapatkan sertifikat jaminan fidusia, terlebih dahulu harus melalui notaris untuk mendapatkan akta jaminan fidusia. Akta notaris tersebut bersifat Partij Akte yaitu Akta yang dibuat "di hadapan" (ten overstaan) Notaris antara kreditor dan debitor. Artinya bahwa dalam memperoleh akta jaminan fidusia secara notariil harus dihadiri kedua pihak yaitu pihak kreditur (penerima fidusia) dan pihak debitur (pemberi fidusia). Hal ini diatur dalam PP No. 86 Tahun 2000 tentang Tata cara Pendaftaran fidusia dan Biaya Pendaftaran fidusia.

Menurut UU No. 30 Tahun 2004 Tentang Jabatan Notaris disebutkan bahwa didalam proses pembuatan satu akta harus "dihadiri oleh para penghadap, dihadiri oleh paling sedikit dua saksi, dibacakan saat itu juga oleh notaris di depan para penghadap dan saksi, di tanda tangani saat itu juga oleh notaris dan kedua penghadap serta kedua saksi tersebut, dan masing-masing pihak diberikan salinan akta tersebut".

Dalam Undang-undang Jaminan fidusia, secara implisit ditentukan bahwa benda/barang yang dibebani dengan jaminan fidusia wajib didaftarkan. Pendaftaran benda yang dibebani dengan jaminan fidusia dilaksanakan di tempat kedudukan pemberi fidusia, pendaftaran ini mencakup benda, baik yang berada di dalam maupun di luar wilayah Negara Republik Indonesia untuk memenuhi asas publisitas, sekaligus merupakan jaminan 
kepastian terhadap kreditur lainnya. Tempat pendaftaran atau lembaga pendaftaran jaminan fidusia adalah Kantor Pendaftaran Fidusia (KPF) yang berada dalam lingkup Departemen Kehakiman (Pasal 12 undang-undang jaminan fidusia). ${ }^{2}$

Setelah adanya permohonan pendaftaran, KPF mencatat jaminan fidusia dalam Buku Daftar Fidusia pada tanggal yang sama dengan tanggal penerimaan permohonan pendaftaran jaminan fidusia, ketentuan ini dimaksudkan agar KPF tidak melakukan penilaian terhadap kebenaran yang dicantumkan dalam pernyataan pendaftaran jaminan fidusia, akan tetapi hanya melakukan pengecekan data. ${ }^{3}$

Setelah pendaftaran jaminan fidusia dilakukan, KPF menerbitkan dan menyerahkan kepada penerima fidusia sertifikat jaminan fidusia pada tanggal yang sama dengan tanggal penerimaan permohonan pendaftaran jaminan fidusia. Sebagai bukti bahwa penerima fidusia memiliki hak fidusia tersebut, maka kepadanya diserahkan dokumenyang disebut dengan "Sertifikat Jaminan Fidusia".

\section{Eksekusi Jaminan Fidusia}

Eksekusi dalam bahasa Belanda disebut Executie atau Uitvoering, dalam kamus hukum diartikan sebagai Pelaksanaan Putusan Pengadilan. Menurut Pasal 29 UUJF, eksekusi adalah Pelaksanaan titel eksekutorial oleh Penerima Fidusia, berarti eksekusi langsung dapat dilaksanakan tanpa melalui pengadilan dan bersifat final serta mengikat para pihak untuk melaksanakan putusan tersebut.

Menurut R. Subekti, eksekusi adalah Upaya dari pihak yang dimenangkan dalam putusan guna mendapatkan yang menjadi haknya dengan bantuan kekuatan hukum, memaksa pihak yang dikalahkan untuk melaksanakan putusan, lebih lanjut dikemukakannya bahwa pengertian eksekusi atau pelaksanaan putusan, mengadung arti, bahwa pihak yang dikalahkan tidak mau melaksanakan putusan tersebut

\footnotetext{
${ }^{2}$ Munir Fuady, Jaminan Fidusia, (Bandung. PT. Citra aditya, 2000), h. 175

${ }^{3}$ Purwahid Patrik dan Kashadi, Hukum Jaminan Edisi Revisi Dengan UUHT, (Semarang. Universitas Diponegoro, 2008), h. 43
}

secara sukarela, sehingga putusan itu harus dipaksakan padanya dengan bantuan kekuatan hukum. Dengan kekuatan hukum ini dimaksudkan pada polisi, kalau perlu polisi militer (Angkatan bersenjata) ${ }^{4}$

Sedangkan yang dimaksud perjanjian fidusia adalah perjanjian hutang-pihutang kreditur kepada debitur yang melibatkan penjaminan. Jaminan tersebut kedudukannya masih dalam penguasaan pemilik jaminan. Tetapi untuk menjamin kepastian hukum bagi kreditur maka dibuat akta yang dibuat oleh notaris dan didaftarkan ke KPF. Setelah itu kreditur akan memperoleh sertifikat jaminan fidusia berirahirah "Demi Keadilan Berdasarkan Ketuhanan Yang Maha Esa". Sertifikat tersebut memiliki kekuatan eksekutorial langsung apabila debitur melakukan pelanggaran perjanjian fidusia (parate eksekusi), sesuai UUJF.

Akta di bawah tangan bukanlah akta otentik yang memiliki nilai pembuktian sempurna. Sebaliknya, akta otentik adalah akta yang dibuat oleh atau di depan pejabat yang ditunjuk oleh Undang-Undang dan memiliki kekuatan pembuktian sempurna. Untuk akta yang dilakukan di bawah tangan biasanya harus diotentikkan ulang oleh para pihak jika hendak dijadikan alat bukti yang sah, misalnya di pengadilan.

Apabila debitur mengalihkan benda objek fidusia yang dilakukan dibawah tangan kepada pihak lain, tidak dapat dijerat dengan UUJF karena tidak sah atau legalnya perjanjian jaminan fidusia yang dibuat. Mungkin saja debitur yang mengalihkan barang objek jaminan fidusia dilaporkan atas tuduhan penggelapan jika pengalihan tersebut atas pengalihan kepemilikan sebagaimana tercantum dalam Pasal 372 KUHPidana

Jika debitur wanprestasi, maka menurut Pasal 29 UUJF, obyek jaminan fidusia dapat dilakukan eksekusi dengan cara : a. Pelaksanaan titel eksekutorial sebagaimana dimaksud dalam Pasal 15 (2) oleh Penerima Fidusia; b. Penjualan benda yang menjadi objek Jaminan Fidusia atas kekuasaan Penerima Fidusia sendiri melalui

${ }^{4}$ Subekti, Hukum Acara Perdata, (Bandung : PT. Bina Cipta 1989), h. 130. 
pelelangan umum serta mengambil pelunasan pihutangnya dari hasil penjualan; c. Penjualan di bawah tangan yang dilakukan berdasarkan kesepakatan pemberi dan penerima Fidusia jika dengan cara demikian dapat diperoleh harga tertinggi yang menguntungkan para pihak.

Kemudian pada butir berikutnya dijelaskan bagaimana mekanisme interpretasi dari penjualan bawah tangan pada butir 2 sebagai berikut: "Pelaksanaan penjualan sebagaimana dimaksud dalam ayat (1) huruf c dilakukan setelah lewat waktu 1 (satu) bulan sejak diberitahukan secara tertulis oleh pemberi dan penerima fidusia kepada pihak-pihak yang berkepentingan dan diumumkan sedikitnya dalam 2 (dua) surat kabar yang beredar di daerah yang bersangkutan".

Setelah syarat diatas dipenuhi, maka dalam pelaksanaan eksekusi jaminan fidusia, debitur wajib menyerahkan benda yang menjadi obyek jaminan fidusia. Apabila debitur tidak menyerahkan jamian fidusia, kreditur berhak mengambil benda yang menjadi obyek jamian fidusia tersebut dengan meminta bantuan pihak yang berwenang. Bantuan pihak yang berwenang ini menjadi wajib setelah dikeluarkannya Peraturan Kepala Kepolisian Indonesia nomor 8 tahun 2011 tentang Pengamanan Eksekusi Jaminan Fidusia (Perkap RI Nomor 8 tahun 2011).

Pasal 6 Perkap RI nomor 8 tahun 2011 tersebut menyatakan: "Pengamanan terhadap objek jaminan fidusia dapat dilaksanakan dengan persyaratan : a. ada permintaan dari pemohon; b. memiliki akta jaminan fidusia; c. jaminan fidusia terdaftar pada Kantor Pendaftaran Fidusia; d. memiliki sertifikat jaminan fidusia; dan e. jaminan fidusia berada di wilayah negara Indonesia.

Mengenai proses pengamanan eksekusi atas jaminan fidusia ini tercantum dalam pasal 7 Perkap RI No. 8 tahun 2011, dimana permohonan pengamanan eksekusi tersebut harus diajukan secara tertulis oleh penerima jaminan fidusia atau kuasa hukumnya kepada Kapolda atau Kapolres tempat eksekusi dilaksanakan. Pemohon wajib melampirkan surat kuasa dari penerima jaminan fidusia bila permohonan diajukan oleh kuasa hukum penerima jaminan fidusia.

Untuk pengajuan permohonan eksekusi, sebagaimana tercantum pada pasal 8, pihak pemohon eksekusi harus melampirkan: 1 . Salinan akta jaminan fidusia; 2 . Salinan sertifikat jaminan fidusia; 3 . Surat peringatan kepada Debitur untuk memenuhi kewajibannya, dalam hal ini telah diberikan pada Debitur sebanyak 2 kali dibuktikan dengan tanda terima; 4. Identitas pelaksana eksekusi; 5. Surat tugas pelaksanaan eksekusi.

Pada butir berikutnya dijelaskan bahwa: "Surat peringatan kepada Debitur sebagaimana dimaksud pada ayat (1) huruf c telah diberikan sebanyak 2 (dua) kali, yang dibuktikan dengan tanda terima". Dalam hal hasil eksekusi melebihi nilai seluruh sisa hutang debitur, kreditur wajib mengembalikan kelebihan tersebut kepada debitur, namun apabila hasil eksekusi tidak mencukupi untuk pelunasan hutang, debitur tetap bertanggung jawab atas hutang yang belum dibayar.

\section{Aspek Hukum Perlindungan Konsumen Dalam Penyitaan Fidusia}

Istilah konsumen berasal dari bahasa Inggris yaitu consumer yang artinya setiap orang yang menggunakan barang atau jasa. Seringkali konsumen berada dalam posisi yang lemah karena adanya faktor "membutuhkan" sehingga perlindungan hukum terhadap konsumen sangat diharapkan sebagai penyeimbang posisi dalam hubungannya dengan pelaku usaha, mengingat salah satu sifat sekaligus tujuan hukum adalah memberikan perlindungan kepada masyarakat. Perkembangan perlindungan terhadap konsumen mengenal tiga adagium yaitu : ${ }^{5}$ Pertama, Caveat emptor, yaitu istilah Latin untuk let the buyer aware (konsumen harus berhati-hati). Hal ini berarti bahwa sebelum konsumen membeli sesuatu, maka ia harus waspada terhadap kemungkinan adanya cacat pada barang; yang kedua Caveat Venditor, caveat venditor (let the producer aware) yang berarti bahwa produsen harus berhati-

\footnotetext{
${ }^{5}$ Subekti, Hukum Acara Perdata, h.100
} 
hati. Doktrin ini menghendaki agar produsen, dalam memproduksi dan memasarkan produknya, berhati-hati dan memperhatikan kepentingan masyarakat luas; yang ketiga, The privity of contract yang mempunyai arti pelaku usaha mempunyai kewajiban untuk melindungi konsumen, tetapi hal itu baru dapat dilakukan jika diantara mereka telah terjalin suatu hubungan kontraktual. Pelaku usaha tidak dapat disalahkan diluar hal-hal yang diperjanjikan. Dengan demikian konsumen dapat menggugat berdasarkan wanprestasi. Hal ini sesuai dengan ketentuan dalam pasal 1340 BW yang menyatakan tentang ruang lingkup berlakunya perjanjian hanyalah antara pihakpihak yang membuat perjanjian saja.

Ketiga adagium diatas dalam UU nomor 8 tahun 1999 tentang Perlindungan Konsumen (UUPK) dijabarkan ke dalam beberapa asas yaitu: 1. Asas manfaat, 2. Asas keadilan, 3. Asas keseimbangan, 4. Asas keamanan dan keselamatan konsumen, dan 5. Asas kepastian hukum.

Penulis menggunakan adagium ketiga untuk menyelesaikan permasalahan antara kreditur dan debitur dalam hal penyitaan jaminan fidusia yang nantinya dijabarkan dalam prinsip perlindungan konsumen menurut UUPK. Hubungan antara kreditur dan debitur diawali dengan adanya perjanjian, dengan demikian berlakulah prinsip-prinsip hukum perjanjian mengenai hal ini seperti, bahwa perjanjian adalah kesepakatan antara dua pihak atau lebih dalam posisi yang seimbang (dalam UUPK diakomodir dengan prinsip keseimbangan). Pemakaian klausula baku yang hanya menempatkan kreditur sebagai pihak yang mau tidak mau harus membubuhkan tanda-tangan mengandung arti bahwa kedudukan antara kreditur dan debitur menjadi tidak seimbang.

Prinsip hukum perjanjian yang berikutnya adalah bahwa sebuah perjanjian berlaku seperti undang-undang bagi para pembuatnya (pasal 1338 BW). Prinsip ini mengandung pengertian secara impisit bahwa para pihak dalam hal perjanjian adalah menjadi seorang pembuat undang-undang dimana wilayah berlakunya terbatas bagi pembuatnya saja. Para pihak bebas menentukan klausul yang akan dijadikan undang-undang asalkan ditaati bersama. Dengan demikian, maka seharusnya perjanjian itu harus dibuat oleh para pihak yang layaknya para pihak tersebut adalah dua orang pembuat undang-undang (legal drafter) dan jika tidak, maka pihak yang satu tidak wajib untuk mentaati undang-undang (perjanjian) tersebut.

\section{Fidusia Dalam Hukum Islam}

Jaminan dalam Islam biasanya diatur dalam bab rahn, rahn yang secara etimologi memiliki arti tetap atau kontinyu ini memiliki banyak definisi yang lainnya. Rahn juga memiliki arti lain yaitu tertahan, seperti terdapat dalam al-Qur'an surat Muddatstsir ayat 38 yang berbunyi :

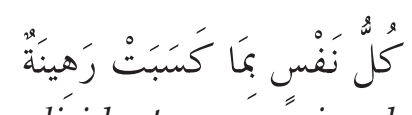

Artinya : "Tiap-tiap diri bertanggúng jawab (tertahan) atas apa yang telah diperbuatnya."(Q.S. Al-Muddatstsir:38)

Kata rahinah disini diartikan tertahan, ${ }^{6}$ sebagaimana kita ketahui barang jaminan gadai biasanya dikuasai oleh debitur. Sedangkan dalam kamus istilah keuangan dan perbankan syariah Bank Indonesia Direktorat Perbankan Syariah mengartikan rahn adalah penyerahan barang sebagai jaminan untuk mendapatkan hutang.

Rahn atau lebih dikenal dengan gadai memiliki definisi dalam terminologi fiqh secara umum yaitu menahan suatu barang dengan suatu hakyangmemungkinkan dapat dipenuhi dari barang tersebut, artinya barang tersebut dijadikan penguat atau jaminan terpenuhinya hak. ${ }^{7}$

Sedangkan syarat-syarat rahn para ulama fiqh menyusunnya sesuai dengan rukun rahn

${ }^{6}$ Prof. Dr. Abdullah bin Muhammad ath-Thayar, Prof. Dr. Abdullah bin Muhammad al-Muthliq, dan Dr. Muhammad bin Ibrahim Alu Musa, Al-Figh AlMuyassarah, Qismul Mu'amalah, (cetakan pertama, tahun $1425 \mathrm{H}$, Madar al-Wathani lin Nasyr, Riyadh, KSA), h. 115.

${ }^{7}$ Wahbah Al-Zuhaili, Al-Mu'amalat Al-Maliyyah AlMu'ashirah Buhuts Wa Fatawa Wa Hulul, (Beirut: Dar AlMu'ashirah, 2002), h. 82. 
itu sendiri. Dengan demikian syarat-syarat rahn adalah seperti disebutkan di bawah ini : ${ }^{8}$ 1. Syarat yang terkait dengan orang berakad (rahin dan murtahin) adalah cakap bertindak hukum. Kecakapan bertindak hukum, menurut jumhur ulama adalah orang yang telah baligh dan berakal. Sedangkan menurut ulama Hanafiyah kedua belah pihak yang berakad tidak disyaratkan baligh, tetapi cukup berakal saja. Oleh sebab itu, menurut mereka anak kecil yang mumayyiz boleh melakukan akad rahn asal mendapat persetujuan dari walinya; 2. Syarat yang terkait dengan shighat, ulama Hanafiyah berpendapat dalam akad itu rahn tidak boleh dikaitkan oleh syarat tertentu Syarat yang dibolehkan itu misalnya, untuk sahnya rahn, pihak pemberi hutang minta agar akad itu disaksikan oleh dua orang saksi; 3. Syarat yang terkait dengan hutang (marhun bih) : a. Merupakan hak yang wajib dikembalikan kepada yang memberi hutang, b. Hutang itu boleh dilunasi dengan jaminan, c. Hutang tersebut jelas dan tertentu; 4. Syarat yang terkait dengan barang yang dijadikan jaminan (marhun), menurut ulama fiqh syarat-syaratnya adalah sebagai berikut: 1 . Barang jaminan itu boleh dijual dengan nilainya seimbang dengan hutang, 2. Berharga dan boleh dimanfaatkan, 3. Jelas dan tertentu, 4. Milik sah orang yang berhutang, 5. Tidak terkait dengan hak orang lain, 6. Merupakan harta utuh, 7. Boleh diserahkan materinya maupun manfaatnya.

Di samping syarat-syarat di atas, para ulama fiqh sepakat menyatakan bahwa ar-Rahn itu baru dianggap sempurna apabila barang yang dirahn-kan itu secara hukum sudah berada di tangan pemberi hutang, dan uang yang dibutuhkan telah diterima peminjam uang. Syarat yang terakhir (kesempurnaan ar-rahn) oleh para ulama disebut sebagai qabdh al-marhun (barang jaminan dikuasai secara hukum). Syarat ini menjadi penting karena Allah dalam surat al-Baqarah ayat $283^{9}$ menyatakan "fa rihanun

\footnotetext{
${ }^{8}$ Abdul Rahman Ghazaly, Ghufron Ihsan, Sapiudin Shidiq, Figh Muamalah, (Jakarta: kencana prenada media group, 2010), h. 267-268

${ }^{9} \mathrm{Al}$-quran dan terjemahnya wakaf dari pelayan dua tanah suci raja Abdullah bin abdul aziz ali sa'ud surat al-baqarah, h. 71
}

magbudhah" yang memiliki makna barang jaminan itu dikuasai secara hukum.

Rahn Tasjily mempunyai arti jaminan dalam bentuk barang atau hutang tetapi barang jaminan tersebut (marhun) tetap berada dalam penguasaan (pemanfaatan) rahin dan bukti kepemilikannya diserahkan kepada murtahin. ${ }^{10}$ Untuk Rahn Tasjily barang yang digunakan untuk jaminan lebih dikhususkan kepada barang bergerak.

Latar belakang yang paling utama dalam pembuatan fatwa ini adalah agar cara dalam menjalankan transaksi Rahn Tasjily sesuai dengan prinsip-prinsip syariah, maka dibuatlah fatwa tentang Rahn Tasjily No : 68/DSN-MUI/III 2008. Dan prinsip-prinsip syariah itu sendiri antara lain adalah tidak mengandung unsur-unsur sebagai berikut: a. Riba, b. Gharar atau ketidak jelasan, c. Dharar atau merugikan/menzalimi pihak lain, d. Jahala atau tidak transparan ${ }^{11}$. Pijakan untuk menetapkan fatwa tentang Rahn Tasjily antara lain adalah :12

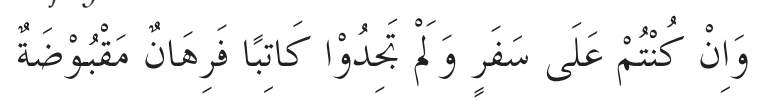

Dan apabila kamu dalam perjalanan sedang kamu tidak memperoleh juru tulis maka hendaklah ada barang tanggungan yang dipegang (QS. AlBaqarah : 283)

Hadis nabi Muhammad SAW sebagai berikut :

Hadis dari Aisyah r.a.

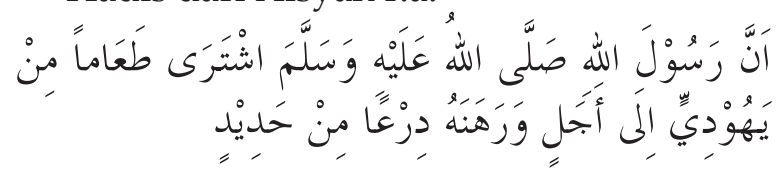

Sesungguhnya Rasulullah SAW pernah membeli makanan dengan berhutang dari seorang yahudi, dan Nabi menggadaikan sebuah baju besi kepadanya (HR al-Bukhari dan Muslim)

Hadis Abu Hurairah, Nabi Muhammad SAW bersabda:

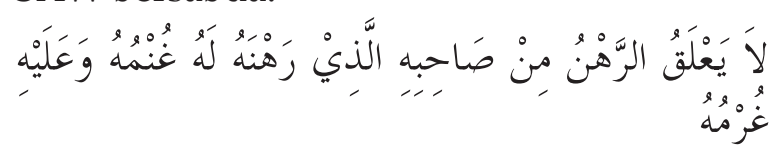

\footnotetext{
${ }^{10}$ Fatwa DSN-MUI 6 Maret 2008

${ }^{11}$ Gemala Dewi dkk. Hukum Perikatan Islam di Indonesia, cetakan ke-2. (Jakarta: Kencana Prenada Media Group, 2006), h. 186

${ }^{12}$ Fatwa DSN-MUI
} 
Tidak terlepas kepemilikan barang gadai daripemilik yang menggadaikannya. Ia memperoleh manfaat dan menanggung resikonya (HR. Nabi riwayat Syafi'i, al Daraquthni dan Ibnu Majah)

Hadis dari Abu Hurairah bahwa Nabi SAW bersabda

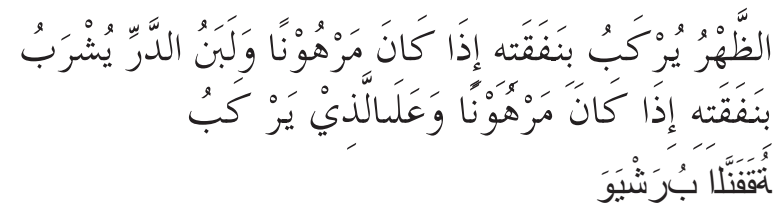

Tunggangan (kendaraan) yang digadaikan boleh dinaiki dengan menanggung biayanya dan binatang ternak yang digadaikan dapat diperah susunya dengan menanggung biayanya. Orang yang menggunakan kendaraan dan memerah susu tersebut wajib menanggung biaya perawatan dan pemeliharaan. (HR Jamaah, kecuali Muslim dan Nasa'i)

Ijma' Para ulama sepakat membolehkan akad Rahn $n^{13}$, berdasarkan kaidah fiqh:

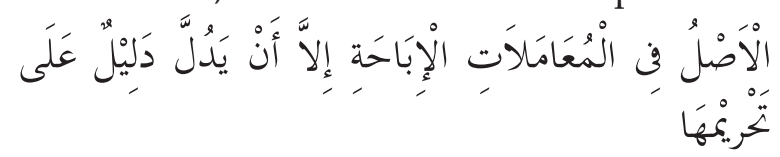

Pada dasarnya segala bentuk muamálat boleh dilakukan kecuali ada dalil yang mengharamkannya.

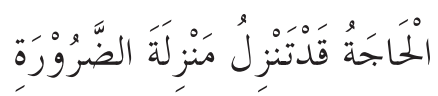

Keperluan dapát menduduki posisi darurat

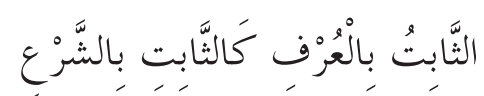

Sesuatu yang berlaḱú b́erdasarkán adat kebiasaan sama dengan sesuatu yang berlaku berdasarkan syara' ( selama tidak bertentangan dengan syari'at).

Setelah menimbang melalui dasar hukum Islam yang telah ada, fatwa DSN-MUI akhirnya memutuskan untuk membolehkan Rahn Tasjily dengan ketentuan sebagai berikut : ${ }^{14} \mathrm{a}$. Rahin menyerahkan bukti kepemilikan barang kepada murtahin; b. Penyimpanan barang jaminan dalam bentuk bukti yang sah kepemilikan atau sertifikat tersebut tidak memindahkan kepemilikan barang ke murtahin. Dan apabila 181

${ }^{13}$ al-Zuhaili, al Fiqh al Islami wa adillatuhu, 1985,V:

${ }^{14}$ Fatwa DSN-MUI terjadi wanprestasi atau tidak dapat melunasi hutangnya, marhun dapat dijual paksa atau dieksekusi langsung baik melalui lelang atau dijual ke pihak lain sesuai prinsip syariah; c. Rahin memberikan wewenang kepada murtahin untuk mengeksekusi barang tersebut apabila terjadi wanprestasi atau tidak dapat melunasi hutangnya; d. Pemanfaatan barang marhun oleh rahin harus dalam batas kewajaran sesuai dengan kesepakatan; e. Murtahin dapat mengenakan biaya pemeliharaan dan penyimpanan barang marhun (berupa bukti sah kepemilikan atau sertifikat) yang ditanggung oleh rahin; f. Besaran biaya pemeliharaan dan penyimpanan barang marhun tidak boleh dikaitkan dengan jumlah pinjaman yang diberikan; g. Besaran biaya sebagaimana dimaksud huruf e tersebut didasarkan pada pengeluaran yang riil dan beban lainnya berdasarkan akad ijarah; h. Biaya asuransi pembiayaan Rahn Tasjily ditanggung oleh rahin.

Untuk ketentuan yang pertama setelah rahin hanya menyerahkan bukti kepemilikan barang sebagai marhun kepada murtahin, karena marhun disini berupa barang bergerak atau jaminan fidusia. Setelah bukti kepemilikan tersebut diserah-terimakan bukan berarti serta-merta memindahkan kepemilikan marhun tersebut kepada murtahin, melainkan apabila terjadi wanprestasiatau tidak dapat melunasi hutangnya, marhun dapat dijual paksa atau dieksekusi langsung melalui lelang atau dijual ke pihak lain sesuai dengan prinsip syariah. Prinsip sayriah dalam lelang adalah sesuai dengan yang diajarkan oleh Rasulullah SAW.

\section{Penyitaan Jaminan Fidusia Berdasarkan Prinsip-Prinsip Syariah}

Dalam transaksi seperti rahn tasjily yang menggunakan barang bergerak sebagai barang jaminan adalah merupakan suatu penanggulangan resiko kerugian apabila terjadi wanprestasi. Namun tidak boleh mengesampingkan prinsip-prinsip syariah yang ada dalam pelaksanaan penyitaan apabila telah terjadi wanprestasi. 
Wanprestasi yang biasa terjadi adalah ketidakmampuan rahin untuk melunasi hutangnya kepada murtahin. Terkadang murtahin hanya memikirkan nasibnya sendiri tanpa meninjau lebih lanjut penyebab rahin tidak dapat melunasi hutangnya dengan melakukan penyitaan sepihak.

Sebagaimana yang telah diketahui, prinsip-prinsip syariah dalam transaksi secara umum adalah tidak mengandung riba, tidak gharar (unsur ketidakjelasan), tidak dharar atau merugikan pihak lain, dan harus transparan. ${ }^{15}$ Prinsip-prinsip dalam penyitaan memiliki spesifikasi tersendiri.

Penyitaan yang dilakukan biasanya tidak mempedulikan hak-hakdari rahin. Pihak lembaga keuangan di lapangan banyak menggunakan jasa debt colector yang secara sepihak langsung mengambil barang yang dijaminkan dan tidak sedikitpun menggunakan prinsip-prinsip Islam dalam penyitaan yang dilakukan. Padahal yang melakukan transaksi dan penyitaan kebanyakan adalah pemeluk agama Islam. Hal ini dapat menjadikan perkembangan perluasan kewenangan Peradilan Agama menjadi stagnan, karena Pengadilan Agama secara sesungguhnya mempunyai kewenangan absolut dalam mengadili sengketa ekonomi syariah, termasuk rahn tasjily.

Penyitaan dalam Islam telah ada sejak zaman Rasulullah SAW, pada saat itu Rasulullah menyita harta Muadz, kemudian menjualnya dan digunakan untuk melunasi hutang Muadz, seperti dalam hadis berikut ini ${ }^{16}$ :

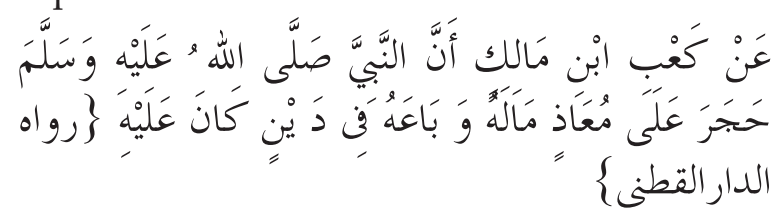

Artinya" : Sesungguhnya Nabi shallallahu 'alaihi wa sallam. pernah menyita harta Mu'adz dan menjualnya untuk membayar hutangnya". (HR. ad-Daar al-Quthni)

\footnotetext{
${ }^{15}$ Gemala Dewi dkk, Hukum perikatan Islam Di Indonesia, (Jakarta, Kencana Prenada Media Group, 2006), h: 186

${ }^{16}$ Muhammad bin Ali bin Muhammad AsySyaukani, Nailul Authar Juz V, (Mesir: Syirkah Maktabah wa Matba'ah Muthafa al-Halaby wa Auladuhu, t.th.), h. 275
}

Dengan adanya hadis diatas dapat diketahui bahwa penyitaan dalam Islam itu diperbolehkan, karena Rasulullah SAW sendiri pernah melakukannya. Namun penyitaan seperti apa yang diperbolehkan dalam Islam, pastilah penyitaan yang tidak bertentangan dengan aturan-aturan dalam syariah atau hukum Islam.

Di dalam hukum Islam, apabila seseorang akan mengadakan jual-beli, sewa- menyewa dan hutang-piutang atau transaksi bisnis lainnya yang tidak secara tunai, maka hendaklah ditulis. Sebagimana firman Allah subhanahu wa ta'ala dalam QS. al-Baqarah ayat $282^{17}$ :

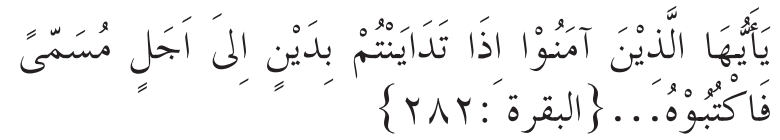

Artinya" : Hai orang-orang yang beriman apabila kamu bermuamalah tidak secara tunai untuk waktu yang di tentukan maka hendaklah kamu menuliskanya..."

Telah jelas kiranya bila dalam bertransaksi sesuai dengan prinsip Islam, maka menuliskan transaksi yang dilakukan adalah sebagai pijakan hukum yang digunakan apabila di kemudian hari terjadi hal-hal yang tidak diinginkan, seperti kejadian wanprestasi oleh salah satu pihak. Selain itu apabila dalam mengadakan akad jual beli atau hutang-piutang sedangkan sudah ditentukan akad pembayaranya maka hendaklah punya jaminan sebagai kekuatan hukum untuk menjamin hutangnya. Di dalam hukum Islam juga dijelaskan melalui makna tersirat dari ayat ini, bahwa apabila terjadi perjanjian hutang-piutang dalam jangka waktu tertentu maka wajiblah janji itu dipenuhi dan pihak yang berhutang perlu membayar hutang itu menurut perjanjian.

Dalam penyitaan jaminan pada Rahn Tasjily pun juga demikian, penyitaan yang dilakukan harus dengan prosedur syariah. Dalam Kompilasi Hukum Ekonomi Islam (KHES) dijelaskan pada pasal 364 pasal 1 tentang penjualan harta rahn disebutkan bahwa murtahin harus memperingatkan Rahin untuk segera melunasi hutangnya apabila telah jatuh tempo. Apabila

${ }^{17} \mathrm{Al}$-Quran dan terjemahnya wakaf dari pelayan dua tanah suci, $\mathrm{h}: 70$ 
belum ada peringatan dari murtahin untuk melunasi hutang dari rahin, maka penyitaan belum bisa dilakukan.

Setelah prosedur diatas dipenuhi dan telah sampai pada waktu yang ditetapkan maka pihak berhutang wajib untuk menyelesaikan hutangnya, jika ia mengalami kesulitan dalam melunasi hutangnya hendaklah diberi kelonggaran dan hal ini di jelaskan oleh Allah dalam QS. al-Baqarah ayat $280^{18}$ :

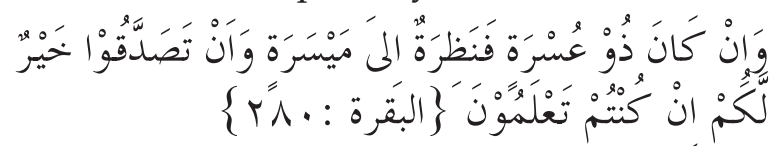

Artinya" : Dan jika ( orang berhutang') itu dalam kesukaran, maka berilah tangguh sampai ia kelapangan dan menyedekahkan sebahagian atau semuanya hutang itu lebih baik bagimu jika kamu mengetahui."

Sebelum penyitaan dilakukan hendaknya diberikan kelonggaran atau kesempatan untuk melunasi kredit yang masih macet, dalam Islam penyitaan tidak boleh serta-merta dilakukan tanpa melalui proses pemberian jangka waktu tertentu untuk mengatasi kredit macet yang terjadi. Setelah pemberian kelonggaran atau jangka waktu untuk pelunasan tersebut telah dilakukan, sedangkan pihak debitur tetap tidak dapat melunasinya, maka murtahin dapat meminta ganti rugi kepada rahin.

Dalam konsep ekonomi Islam menjadi sebuah anjuran kepada murtahin untuk memberikan penangguhan hutang terhadap rahin yang tidak mampu melunasi hutangnya, bahkan bagi murtahin yang mengikhlaskan untuk membebaskan hutang dijanjikan oleh Allah SWT pahala untuknya. Sebagaimana terdapat dalam ayat al-Quran surat al-Baqarah ${ }^{19} \mathrm{di}$ bawah ini :

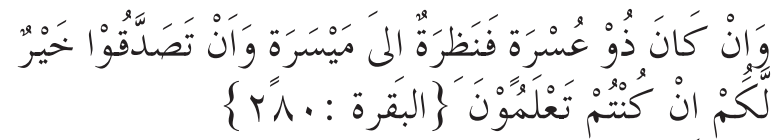

Artinya : "Dan jika (orang berhutang) itu dalam kesukaran, maka berilah tangguh sampai ia kelapangan dan menyedekahkan sebahagian atau

\footnotetext{
${ }^{18} \mathrm{Al}$-quran dan terjemahnya wakaf dari pelayan dua tanah suci, $\mathrm{h}: 70$

${ }^{19} \mathrm{Al}$-quran dan terjemahnya wakaf dari pelayan dua tanah suci, h : 70
}

semuanya hutang itu lebih baik bagimu jika kamu mengetahui."

Apabila ada seseorang yang berada dalam situasi sulit, atau akan terjerumus dalam kesulitan bila membayar hutangnya, maka tangguhkan penagihan sampai dia lapang. Jangan menagihnya jika kamu mengetahui dia sempit, apalagi memaksanya membayar dengan sesuatu yang amat dia butuhkan. ${ }^{20}$

Terdapat alasan logis dalam Islam yang menyarankan bagi murtahin untuk membebaskan hutang bagi rahin. Alasan tersebut adalah seseorang yang dalam kondisi terjerat hutang sedangkan dia tidak mempunyai harta untuk melunasi hutangnya tersebut dikhawatirkan akan terjerumus dalam lembah kejahatan dan menghalalkan segala cara untuk mendapatkan harta dan melunasi hutangnya.

Dalam salah satu hadis Rasulullah SAW disebutkan bahwa apabila ada seseorang yang membebaskan hutang bagi orang lain, maka akan dijanjikan perlindungan oleh Allah SWT. Hal ini dikarenakan orang yang memberi pembebasan hutang telah melindungi orang lain yang berhutang kepadannya dari kelemahan iman dan tindakan yang melanggar hukum Islam. Sebagaimana sabda Rasulullah SAW berikut ${ }^{21}$ :

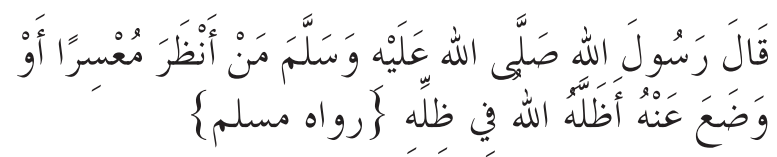

Artinya" : Rasulullah́ śállallahu 'alaihi wa sallam bersabda; Barangsiapa yang menangguhkan pembayaran hutang orang yang berada dalam kesulitan, atau membebaskannya dari hutangnya, maka dia akan di lindungi Allah."

Setelah tahap diatas telah dilalui, kemudian dilakukan tahapan berikutnya yaitu penyitaan. Penyitaan adalah salah satu bentuk solusi bagi murtahin untuk mendapatkan haknya. Rahin yang tidak dapat melunasi hutangnya dapat disita harta jaminannya. Penyitaan ini dapat dilakukan oleh murtahin sendiri sesuai dengan kesepakatan dan akad diawal ataupun

\footnotetext{
${ }^{20}$ M. Quraish Shihab, Tafsir sl-Misbah Jilid 1 ( Jakarta, Lentera Hati, 2002), h : 569

${ }^{21}$ Imam Muslim, Sohih Muslim, Juz II, (Bandung: Dahlan, t.th.), h. 600
} 
melalui pengadilan. Seperti hadis Rasulullah di bawah ini :22

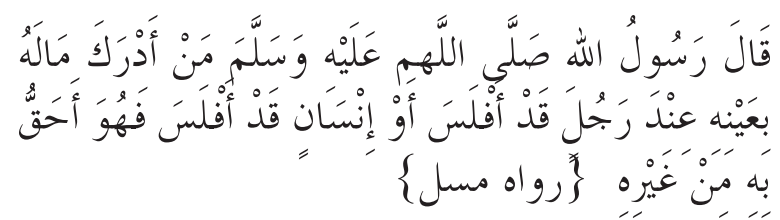

Artinya : "Rasulullah shallallahu 'alaihi wa sallam bersabda; Barangsiapa yang mendapatkan hartanya ditangan orang yang telah pailit, maka ia lebih berhak untuk mengambil harta itu dari pada diambil oleh orang lain."

Makna yang terkandung pada hadis di atas adalah murtahin lebih berhak melakukan penyitaan, dengan demikian penyitaan secara langsung oleh murtahin dianggap sah dan diperbolehkan dalam Islam. Selain hadis diatas terdapat pula hadis lain yang diriwayatkan ad-Daar al-Quthni seperti berikut : ${ }^{23}$

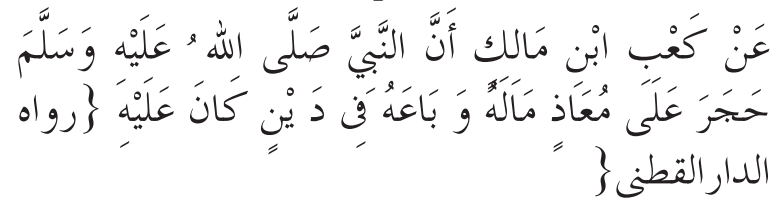

Artinya : "Sesungguhnya Nabi shallallahu 'alaihi wa sallam. pernah menyita harta Mu'adz dan menjualnya untuk membayar hutangnya". (HR. ad-Daar al-Quthni)

Hadis diatas lebih menjelaskan adanya penyitaan yang dilakukan melalui pengadilan, hal ini mengingat bahwa kedudukan Rasullullah SAW pada masa itu selain sebagai Pemimpin Pemerintahan beliau adalah sebagai seorang hakim. Kedua hadis di atas memiliki korelasi bahwa penyitaan memang dibenarkan dalam Islam baik penyitaan yang dilakukan secara langsung oleh murtahin ataupun penyitaan yang dilakukan oleh pengadilan.

Apabila telah jatuh tempo dan murtahin telah mengingatkan rahin untuk melunasi hutangnya, sedangkan rahin tetap tidak dapat melunasi hutangnya, maka marhun dapat dijual secara paksa atau dieksekusi melalui lelang sesuai dengan syariah. ${ }^{24}$ Dari hasil penjualan marhun tersebut digunakan untuk melunasi hutang rahin terhadap murtahin, serta biaya

\footnotetext{
${ }^{22}$ Imam Muslim, Sohih Muslim, Juz II, h. 681

${ }^{23}$ Muhammad bin Ali bin Muhammad AsySyaukani, Nailul Authar Juz V, h. 275

${ }^{24}$ Kompilasi hukum ekonomi Islam, h. 94
}

penyimpanan dan penjualan apabila ada yang belum dibayarkan.

Lelang secara syariah yang dimaksud di sini adalah pelelangan harus berdasarkan kerelaan antar rahin dan murtahin. Selain itu dalam proses lelang harus terhindar dari riba, keharaman, gharar, maysir, serta mengembalikan sisa hasil penjualan barang (marhun). Lelang di dalam Islam lebih dikenal dengan kata muzayadah..$^{25}$ Penjualan dengan cara lelang sudah pernah dilakukan oleh Rasulullah SAW sebagaimana dijelaskan dalam hadis riwayat tirmidzi di bawah ini :

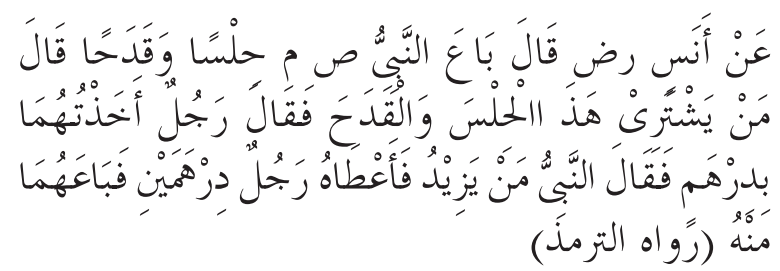

artinya: dari Anas r.a, ia berkata, Rasulullah SAW menjual sebuah pelana dan sebuah mangkok air dengan berkata siapa yang mau membeli pelana dan mangkokini? seorang laki-laki menyahut: aku bersedia membelinya dengan satu dirham. Lalu nabi berkata lagi, siapa yang berani menambahi? Maka diberi dua dirham oleh seorang laki-laki kepada beliau, lalu dijuallah kedua benda itu kepada laki-laki tadi (Riwayat Tirmidzi)

Setelah pembayaran hutang dari hasil penjualan marhun tersebut terlaksana, kelebihan hasil penjualan menjadi milik rahin dan kekurangannya menjadi kewajiban rahin. ${ }^{26}$ Dengan demikian apabila terdapat kelebihan dalam hasil penjualan harus dikembalikan kepada rahin, dan apabila masih kurang dari hasil penjualan marhun maka menjadi kewajiban rahin untuk membayarnya sampai lunas.

Murtahin sebagai pihak yang melakukan sita tidak secara otomatis memiliki harta jaminan yang disita, kecuali harta jaminan memiliki nilai yang sama dengan hutang rahin. Karena di dalam Islam terdapat konsep pemindahan kepemilikan tersendiri. Hal ini adalah salah satu cara Islam dalam melindungi konsumen.

Terdapat beberapa cara pemindahan kepemilikan menurut hukum Islam. Dalam kaitannya dengan rahn tasjily diatas, marhun

\footnotetext{
${ }^{25}$ Hendi suhendi, figh muamalah (Jakarta, Raja grafindo persada, 2010), h. 86

${ }^{26}$ Kompilasi hukum ekonomi Islam, h : 94
} 
hanya dapat dipindahkan kepemilikannya apabila dalam akad telah disepakati apabila terjadi wanprestasi, atau ketidakmampuan nasabah untuk membayar, maka jaminan fidusia dapat dipindahtangankan dengan cara sita. Apabila penyitaan telah dilakukan, maka hak kepemilikan benda yang dijaminkan oleh rahin sepenuhnya menjadi milik murtahin.

\section{Kesimpulan}

Proses penyitaan jaminan fidusia mengenai barang bergerak telah diatur dalam UUJF. Mulai dari diwajibkannya memperoleh akta jaminan fidusia yang dikeluarkan oleh notaris sampai pada tahap mendaftarkan obyek jaminan fidusia ke KPF hingga mendapatkan sertifikat jaminan fidusia.

Banyak terjadi penyimpangan di lapangan dengan tidak didaftarkannya obyek jaminan sampai penggunaan debt collector untuk mengambil barang jaminan secara paksa. Realita ini mendapatkan respon dari aparat kepolisian dengan dikeluarkannya Perkap RI nomor 8 tahun 2011 mengenai pengamanan eksekusi jaminan fidusia.

Dalam hukum perlindungan konsumen terdapat adagium the privity of contract yang

\section{DAFTAR PUSTAKA}

\section{Literatur Buku}

Akbar Silondae, Arus. Aspek Hukum Dalam Ekonomi \& Bisnis. Jakarta : Mitra Wacana Media. tt

Al-Quran dan Terjemahnya wakaf dari pelayan dua tanah suci raja Abdullah bin Abdul Aziz Ali Sa'ud.

Al-Zuhaili, Wahbah. Al-Mu'amalat Al-Maliyyah Al-Mu'ashirah Buhuts Wa Fatawa Wa Hulul. Beirut : Dar Al-Mu'ashirah. 2002.

Asy-Syaukani, Muhammad bin Ali bin Muhammad. Tt. Nailul Authar Juz V. Mesir: Syirkah Maktabah wa Matba'ah Muthafa al-Halaby wa Auladuhu.

Bin Muhammad ath-Thayar, Abdullah; Muhammad al-Muthliq, Abdullah; bin IbrahimAlu Musa, Muhammad. $1425 \mathrm{H}$ cetakan pertama. Al-Figh Al-Muyassarah, menempatkan sebuah perjanjian menjadi hal pokok yang harus ditaati dan perjanjian tersebut harus dibuat dengan kedudukan yang seimbang antara kreditur dan debitur sesuai dengan prinsip keseimbangan dalam UUPK. Hal demikian masih belum dilaksakan dikarenakan kreditur masih menggunakan perjanjian baku yang dalam pasal 18 UUPK dilarang.

Pada dasarnya proses penyitaan menurut UUPF sama dengan rahn tasjily. Perbedaannya hanya pada adanya penundaan pembayaran dalam prinsip syariah.

\section{Saran}

Berdasarkan asas personalitas keislaman, maka umat Islam wajib menyelesaikan sengketa di Pengadilan Agama, yang sekarang telah diperluas termasuk bidang ekonomi Islam seperti rahn tasjily ini. Diharapkan pihak kreditur agar menambahkan beberapa opsi dalam perjanjian baku agar lebih fleksibel sehingga debitur tidak terdominasi dengan adanya perjanjian baku tersebut tetapi masih mempunyai kesempatan untuk memilih. Biaya pendaftaran obyek jaminan fidusia hendaknya ditentukan diawal prosesperjanjiandan ditanggung sama rata antara kreditur dan debitur.

Qismul Mu'amalah. Riyadh, Madar alWathani lin Nasyr.

Dewi, Gemala dkk. Hukum Perikatan Islam di Indonesia, cetakan ke-2. Jakarta, Kencana Prenada Media Group. 2006.

Fuadi, Munir. Jaminan Fidusia. Bandung, PT Citra Aditya Bakti. 2003.

Ghazaly, Abdul rahman. Ihsan, Ghufron. Shidiq, Sapiudin. Figh Muamalah. Jakarta, Kencana Prenada Media Group. 2010.

Konsumentenrecht, Hondius, dalam : Mariam Darus Badrulzaman, Perlindungan Terhadap Konsumen Dilihat Dari Sudut Perjanjian Baku. Bandung, Binacipta. 1976,

Masjchun Sofwan, Sri Soedewi. Himpunan Karya Tentang Hukum Jaminan. Yogyakarta, Liberty. 1982.

Miru, Ahmadi dan Yodo, Sutarman, Hukum 
Perlindungan Konsumen, Jakarta,PT RadjaGrafindo Persada, 2007

Muflih, Muhammad, M.A., Perilaku Konsumen Dalam Perspektif Ilmu Ekonomi Islam, PT RadjaGrafindo Persada, Jakarta, 2006

Muslim, Imam. Sohih Muslim, Juz II. Bandung, Dahlan. tt.

Patrik, Purwahid dan Kashadi, Hukum Jaminan Edisi Revisi Dengan UUHT, Semarang, Universitas Diponegoro, 2008

Prajitno, Andi, Dr.A.A, Drs., S.H., M.Kn, Hukum Fidusia, Problematika Yuridis pemberlakuan Undang-Undang nomor 42 tahun 1999, Malang, Bayu Media Publishing, 2011

Rusyd, Ibn. Bidayatul Mujtahid Wa Nihayatul Muqtashid. jilid II, tt.

Shihab, M. Quraish. Tafsir al-Misbah Jilid 1. Jakarta, Lentera Hati. 2002.

Subekti, Hukum Acara Perdata, Bandung,PT. Bina Cipta, 1989
Sugiyono. Metode Penelitian Pendidikan (Pendekatan Kuantitatif, Kualitatif dan $R \mathcal{E} D$ ). Bandung : Alfabeta. 2009.

Suhendi, Hendi. Figh Muamalah. Jakarta, PT RajaGrafindo Persada Press. 2010.

Syawali, Husni. Hukum Perlindungan Konsumen. Bandung, Mandar Maju. 2000.

Literatur Perundang-undangan

UU No 42 tahun 1999 Tentang Jaminan Fidusia

UU No. 8 tahun Kitab Undang-undang Hukum Perdata

Kompilasi Hukum Ekonomi Islam

Peraturan Kepala Kepolisian Republik Indonesia nomor 8 tahun 2011 Tentang Pengamanan Eksekusi Jaminan Fidusia 1999 tentang Perlindungan Konsumen 